Quebec Cooperative Study of

Friedreich's Ataxia

\title{
Autosomal Recessive Spastic Ataxia of Charlevoix-Saguenay
}

\author{
J. P. BOUCHARD, A. BARBEAU, R. BOUCHARD AND R. W. BOUCHARD*
}

SUMMARY: $A$ new syndrome of autosomal recessive spastic ataxia has been isolated in the Charlevoix. Saguenay region of Quebec. This syndrome is remarkably homogeneous and includes: spasticity, dysarthria, distal muscle wasting, foot deformities, truncal ataxia, absence of sensory evoked potentials in the lower limbs, retinal stri-

RÉSUMÉ: Nous avons isolé dans les comtés de Charlevoix et Saguenay, au Québec, un nouveau syndrome d'ataxie spastique transmit par voie autosomale récessive. Ce syndrome est remarquablement homogène et inclue: spasticité, dysarthrie, fonte musculaire distale, déformités des pieds, ataxie tronculaire, absence de potentiels sensitifs évoqués aux membres inférieurs, striation rétinienne réminescente du stage initial ation reminiscent of early Leber's atrophy and the frequent presence (57\%) of a prolapse of the mitral valve. Biochemically, many cases show impaired pyruvate oxidation, others have hyperbilirubinaemia and some have low serum $\beta$-lipoproteins and HDL apoproteins. These features are similar to those found in trypical Friedreich's ataxia.

de l'atrophie de Leber et enfin la présence fréquence (57\%) d'un prolapsus de la valve mitrale. Biochimiquement plusieurs patients ont un ralentissement du taux d'oxydation du pyruvate, d'autres une hyperbilirubinaemie et quelques uns des valeurs basses de $\beta$-lipoprotéines sériques ou des apoprotéines des HDL. Ces caractéristiques ressemblent à celles de l'ataxie de Friedreich typique.
From l'Hôpital de l'Enfant-Jésus, Quebec City; l'Institut de Cardiologie de Québec; le Centre Hospitalier de I'Université Laval; I'Institut de Psychométrie et de Méthodes Quantitatives de Québec and The Clinical Research Institute of Montreal.

Reprint requests for the complete supplement on Friedreich's ataxia (Phase Two, Part One) to: Dr. André Barbeau, Clinical Research Institute of Montreal, 110 Pine Avenue West, Montreal, Quebec, Canada H2W 1R7.

*With the collaboration of: P. Delisle, A. M. Mathieu, L. Leclerc, G. Turcotte, J. Valero, M. Paquet, P. Cortin and M. Pepin.

\section{INTRODUCTION}

During the past two years, we became aware of a form of hereditary ataxia encountered in a genetically isolated region of Quebec. Some of these patients had been investigated and diagnosed as "atypical Friedreich's ataxia" or a "forme de passage" between Friedreich's ataxia and spastic paraplegia.

In a recent description of patients with Friedreich's ataxia in Quebec, Geoffroy et al. (1976) stated that intermediate and atypical forms seemed to outnumber the classical presentation and gave a comprehensive list of signs and symptoms to help in the differential diagnosis. However, Netsky (1968), in an excellent review, listed an infinite number of permutations and clinical forms in hereditary ataxia but doubted the necessity of describing new diseases.

We have described a syndrome seen in Charlevoix-Saguenay, presenting as a form of familial spastic ataxia and compared it with the clinical picture of pure Friedreich's ataxia in Quebec. It is suggested that both forms possibly originated from a common couple living in Quebec City around 1650 .

\section{The Region and the Population}

Charlevoix County is a mountainous area east of Quebec City on the north shore of the St. Lawrence River. Between 1665 and 1725 , some forty families migrated from the capital, settled around Baie St-Paul and propagated with astonishing fertility. While only sixty miles from Quebec City, there was little population exchange as there were no roads and navigation was hazardous. (Fig. 1).

By 1825 the descendants of these families and a few others had popu- 


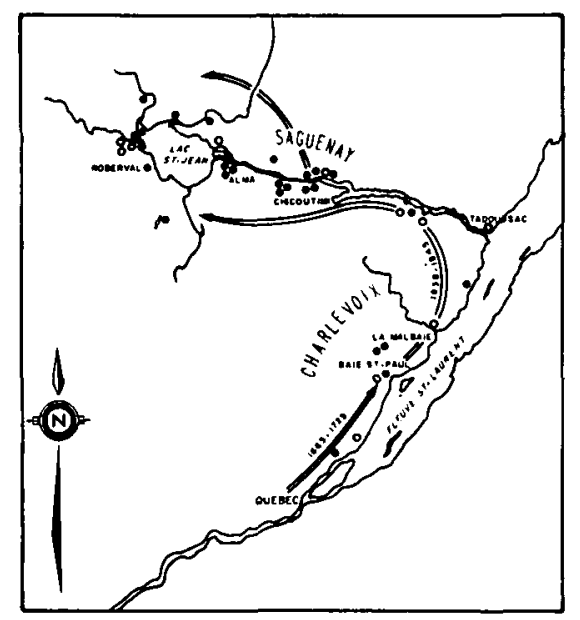

Figure I-Map of the region where familial spastic ataxia is encountered in Quebec. Black dots represent the sibships described in this study and open circles sibships known to have the disease. The arrow traces migration of the population.

lated and developed the county. Between 1838 and 1855 a number of families from Charle voix established themselves in the newly opened Saguenay territory. Until then it had been protected for the fur trade. By 1851 they accounted for more than $80 \%$ of the Saguenay population which was then around 5,000 (or 800 families). In 1977 it is more than 205,000 .

As is the case for another well known isolate in Holmes County, Ohio (Cross and McKusick, 1967 a and b), two other recessive entities have been described from the same pooled population of Charlevoix County and the tributary Saguenay and Lac St-Jean areas. These are tyrosinemia (Laberge, 1969) and familial agenesis of the corpus callosum with sensorimotor neuropathy (Andermann et al., 1976).

\section{The Study}

The disease appears to be transmitted as an autosomal recessive disorder with strong intra and interfamilial similarities. Forty-two patients were examined from 24 sibships and we know of another 24 afflicted individuals not examined. No parent was reported to have the disease. Parents and unaffected siblings were examined in six families and found to be normal. Fourteen patients were admitted to hospital for tests and the results of their investigation are tabulated. The group of 42 forms the basis of the discussion.

\section{a) Sex distribution}

The distribution of male and female cases favored males 3:2 in the 24 sibships (Table 1). In six of these sibships afflicted members are exclusively from one sex. Bell and Carmichael (1939) found the same ratio for recessive spastic ataxia (66 males/48 females), while both sexes were equally distributed in the five other groups of ataxia and spastic paraplegia with recessive or dominant transmission. In the small group described in the Troyer syndrome as spastic ataxia, males outnumbered females $2: 1$ (Cross and McKusick, 1967).

B) Age of Onset

None of the patients ever walked normally, but milestones were not delayed for most of them. Parents noted unsteadiness and frequent falls when the affected children began to walk. This early involvement is common in hereditary spastic ataxia. Uniformity of this character highlights a significant correlation within pairs of siblings for age of onset. This was noted by Bell and Carmichael (1939). Duration of the disease is then simple to calculate.

At the time of the study, the age of our patients was between 9 and 52 years, with a mean of $30.54 \pm 11.20$. The age of patients admitted to hospital for tests ranged between 17 and 43 years, with a mean of $30.07 \pm 7.42$ (Table 1). The disease has a long course and slow progression compared to Friedreich's ataxia. In many cases little evolution occurred after the age of 20.

C) Neurological Signs and Symptoms

(Table 2)

1. Ataxia of gait was present from the beginning of walking in all cases. A few patients denied early walking difficulties, but the family always gave evidence of frequent falls and clumsiness in running. Two patients claimed improvement in childhood, but they deteriorated again in their teens. Progression of ataxia was difficult to delineate. The disease seemed to be stable for long periods and then seemed to worsen over a few years,

None of the patients exhibited truncal ataxia when sitting. Cerebellar manifestations in the upper limbs included clumsiness of the hands with variable degrees of dysrhythmia, slowness of fine and course alternating movements, dyssynergia and past-pointing. These signs in the lower limbs were obscured by stiffness but the heel-to-shin test shows less wavering than one would expect.

2. Dysarthria was always present with a slurred character. The voice was rarely explosive. There was often a break in the normal melody and sudden change of tone. The tongue was never wasted but slow and dysrhythmic in alternate movements without oro-facial dyspraxia.

3 . Nystagmus was present in all cases with the following characteristics: horizontal, of the first and rarely second degree, bi-directional, often with predominance on one side. In addition, there was occasionally a more irregular vertical nystagmus. By comparison, Bell and Carmichael (1939) reported nystagmus in $69 \%$ of their total cases of hereditary ataxia and Geoffroy et al. (1976) in only $42 \%$ of their Friedreich's ataxia patients.

One of the most remarkable features for all the cases of familial spastic ataxia was a gross defect of conjugate pursuit ocular movements. These were dysmetric, saccadic and restricted to the horizontal plane. Wadia and Swami (1971) and Zee et al. (1976) described similar difficulties in hereditary ataxia and the last author implied a specific role for the cerebellum in helping to maintain eccentric gaze, in producing smooth pursuit eye movements and in modulating the amplitude of saccadic eye movements. Electronystagmographic studies in these patients will be presented in a forthcoming paper.

4. Muscle tone was markedly increased in the lower limbs, with polykinetic knee jerks and occasionally clonus at this level. Spasticity often caused internal rotation of the lower limbs and scissoring as the 
TABLE 1

CHARACTERIZATION OF PATIENTS

\begin{tabular}{|c|c|c|}
\hline PATIENTS & EXAMINED & ADMITTED \\
\hline N & 42 & 14 \\
\hline$M$ & 25 & 6 \\
\hline \multicolumn{3}{|l|}{ SEX } \\
\hline $\mathrm{F}$ & 17 & 8 \\
\hline$M$ & $29.40 \pm 12.04$ & $25.83 \pm 6.17$ \\
\hline \multicolumn{3}{|l|}{ AGE } \\
\hline$F$ & $32.23 \pm 9.96$ & $33.25 \pm 6.94$ \\
\hline BOTH SEXES & $30.54 \pm 11.20$ & $30.07 \pm 7.42$ \\
\hline RANGE & $9-52$ & $17-43$ \\
\hline
\end{tabular}

TABLE 2

NEUROLOGICAL SIGNS OF HEREDITARY ATAXIAS IN QUEBEC (\% OF TOTAL NUMBER)

N

\section{ATAXIA OF GAIT}

DYSARTHRIA

NyStagmus

SACCADIC PURSUIT

SPASticity

PATELLAR REFLEX PRESENT

ACHILLES REFLEX PRESENT

ABdoMinal REFLEX PRESENT

EXTENSOR PLANTAR RESPONSE

Post. COLUMN SIGNS (LOWER LIMBS)

SCOLIOSIS $\left(>10^{\circ}\right)$

Pes cavus

WASTED HANDS (MARKED)

\VISUAL ACUITY

RETINAL STRIATIONS

INCONTINENCE (BLADDER AND/OR BOWELS)

CARDiopathy (HYPERTROPHIC)

(MI TRAL VALVE PROLAPSE)

\begin{tabular}{cc}
$\begin{array}{l}\text { FAMILIAL } \\
\text { SPASTIC } \\
\text { ATAXIA }\end{array}$ & $\begin{array}{c}\text { FRIEDREICH'S } \\
\text { ATAXIA } \\
\text { (GEOFFROY 1976) }\end{array}$ \\
\hline$(14)$ & $(33)$ \\
100 & 100 \\
100 & 100 \\
100 & 42.4 \\
100 & -- \\
100 & 15.1 \\
100 & 0 \\
7.1 & 0 \\
57.1 & -- \\
100 & 100 \\
100 & 100 \\
0 & 90.9 \\
85.7 & 96.9 \\
21.4 & -- \\
0 & 45.4 \\
100 & -- \\
64.3 & -- \\
0 & 96.9 \\
57.1 & --
\end{tabular}

TABLE 3

Means of each Ottawa-Wechsler scale adjusted for age $(N=21)$

SCALE MEAN $(z=$ SCORES $)$ :

VERBAL SCALES

INFORMATION

$-0.74$

general Knowledge - Long Term Memory from

EXPERIENCE - EDUCATION

COMPREHENSION

Practical Knowledge and Social Judgment -

Reasoning - Logical SOlutions

DIGIT SPAN

Attention, Concentration, Rote \& Immediate

Memory - Sequencing

ARITHMETIC

$-1.24$

Concentration, Enumerating - Arithmetic

Reasoning - Sequencing

SIHITLARTITíES

- U. 33

Relationship \& Abstract Thinking - Association

of ABstract IDEas

NON VERBAL SCALES (PERFORMANCE)

PICTURE ARRANGEMENT

$-1.39$

Interpretation of Social Situation - Sequencing -

VISUAL ALERTNESS

PICTTURE COMPLETION

$-0.86$

Visual Memory \& Alertness to Details

$-1.30$

BLOCK DESIGN

Reproduce Abstract Design from Pattern - Visual

Perception

OBJECT ASSEMBLY

Reproduce familial forms from Memory - Visual

RETENTION

DIGIT SYMBOL.

$-2.07$

Speed and Accuracy of Learning Meaningless

Symbols - Immediate Visual Memory - Motor Control

\section{TABLE 4}

T-TEST FOR PAIRED DATA BETWEen VERBaL I.Q. AND NON-VERBAL 1.0.

$$
(N=21)
$$

\begin{tabular}{|c|c|c|}
\hline & MEAN & S.D. \\
\hline VERBAL I,Q, & 92.67 & 11.37 \\
\hline NON-VERBAL I.Q. & 71.14 & 13.03 \\
\hline
\end{tabular}

(PERFORMANCE)

SIGNIFICANCE

t 8.11

$P<.01$ 
disease progressed. Tip-toeing was not constant, but appeared early and some patients had previous surgery for elongation of Achilles tendon. Chaddock and Babinski signs were easily elicited in all cases, but in two were associated with equivocal plantar responses. Half of the patients exhibited abdominal cutaneous reflexes and this finding could indicate sparing the direct pyramidal tracts and might explain the lack of scoliosis in this form of spastic ataxia.

5. Posterior column signs in the lower limbs were found in all the ataxic patients. Vibration sense was decreased or absent in the toes and reduced to a lesser degree at the ankle. It was seldom completely abolished at this level even in older patients. Nevertheless, there was progression of this sign as the youngest patients in the group seemed almost normal. Hesitations and a few errors were observed in most adult cases when testing position of the toes. Such defects were not demonstrated in the upper limbs.

Bell and Carmichael (1939) noted that sensory signs are often accessory and not looked for carefully in hereditary ataxia. In a given kindred, the sensory deficit can be extensive (Ferguson and Critchley, 1929) or absent (Cross and McKusick, 1976b). Hogan and Bauman (1977) stated that disturbances in sensations have been described in relatively few patients with familial spastic ataxia, but our group showed a consistent, although not dramatic, pattern of deep sensory involvement.

Cutaneous sensations were normal. In one patient (43 years of age), pricking of the feet provoked triple flexion of the legs before it was perceived as painful. More detailed sensory evaluation with threshold study and concentration of cutaneous receptors are to be done, as suggested by Dyck et al. (1971). Biopsies of sural nerves were performed in four patients and will be reported later.

6. Muscles weakness was discrete, but distal leg atrophy was present in most of the cases, exemplified by the extensor digitorum bre- vis muscle. Other small muscles of the foot were involved and the atrophy sometimes extended to the anterior compartment of the leg.

7. Pes cavus was frequently seen. Only two admitted patients presented otherwise, one with normal feet and the other with flat feet. We found foot deformities in relation to the characteristics already discussed: early distal spasticity, weakness of extensor digitorum brevis with possible spasticity or weakness of the intrinsic muscles as a whole. Equinus was present early.

Clawing of the toes was a distinctive feature of the majority and in some the only noticeable deformity. Prior to or after this clawing, the usual cavus foot was observed as in the other spino-cerebellar degenerative diseases. The amount of varus in the posterior region was distinctive. It was less obvious than the varus of Charcot Marie-Tooth disease or Friedreich's ataxia. The cavitation was located mostly at the forefoot with a plantar thrust of the metatarsals. The mechanism of this thrust was not clearly understood. It could be due to spasticity of the intrinsic muscles, dynamic secondary compensations or a retrograde downward force produced by the clawing. As Tyrer and Sutherland (1961) have shown, many different mechanisms could explain such a deformity. Later in the disease the imbalance between a weak anterior tibialis muscle and a deforming plantar long peroneous acting on the first metatarsal might be important. Defective cerebellar function, as appears to be the case in Friedreich's ataxia, may have an effect.

Many of the factors described can lead to a variety of deformities: equinus, clawing, equinovarus, supinated equinovarus or club feet, slight varus of the posterior part of the foot with marked pronation and equinus of the forefoot. This last deformity, seen in patients late in the disease, can be complex in its pathology and its treatment. Usually the deformities were well tolerated and ranged, for the still active walkers, from a reductible clawing of the toes to a pes cavus with an acceptable degree of varus and supi- nation of the foot. Occasionally, the deformity did not allow a plantar splaying of the foot, worsening the problems of ambulation.

Ankle jerks were absent after 24 years of age. They could be normal or brisk with clonus under that age, thus indicating a progressive sign of the neuronopathy.

8. Hand deformities. There was a high occurrence of atrophy of the small hand muscles, which was important in 5 of the 14 patients admitted for the study. Silver (1966) described similar wasting of the hands and reviewed the literature for this usually rare finding in familial spastic paraplegia. His two families presented little functional deficit in the legs, although examination disclosed spasticity.

Claw hands were relatively rare in hereditary ataxia described by Bell and Carmichael (1939), but more frequent when the disease lasted 20 years or more. This was the case in most of our patients. Marked wasting of the hands is a regular feature of Charcot Marie-Tooth disease and is regarded as evidence of "dying back' neuronopathy. In our cases, atrophy of the hands was a progressive sign and was early and marked in all affected members of two families (Fig. 2). Generalized muscle wasting was not seen, but muscle bulk was moderately and diffusely reduced without severe weakness in some older patients.

9. Incontinence of urine or feces was so rarely reported in hereditary ataxia that Bell and Carmichael (1939) concluded it had "no special significance and may indeed by accidental in character'. Hogan and Bauman (1977) in a review on familial spastic ataxia do not mention it. However, some of the patients reported by Schut (1950) and Landau and Gitt (1951) complained of incontinence or severe constipation.

In our 14 patients admitted to hospital, incontinence was an important feature, as seven acknowledged urine urgency and incontinence, three feces incontinence and three severe constipation. Only three patients had normal bladder and bowel functions. No correlation was found 
between visceral involvement and the patient's age or sex.

10. Other features described in the literature and present in this group were dysphagia (occasional choking either with solid or fluid or both) noted in five patients. Vertigo on movement was reported in another five cases. It was not spinning, but rather an unsteadiness or a movement of the floor. Asymmetry of the face was obvious in two patients.

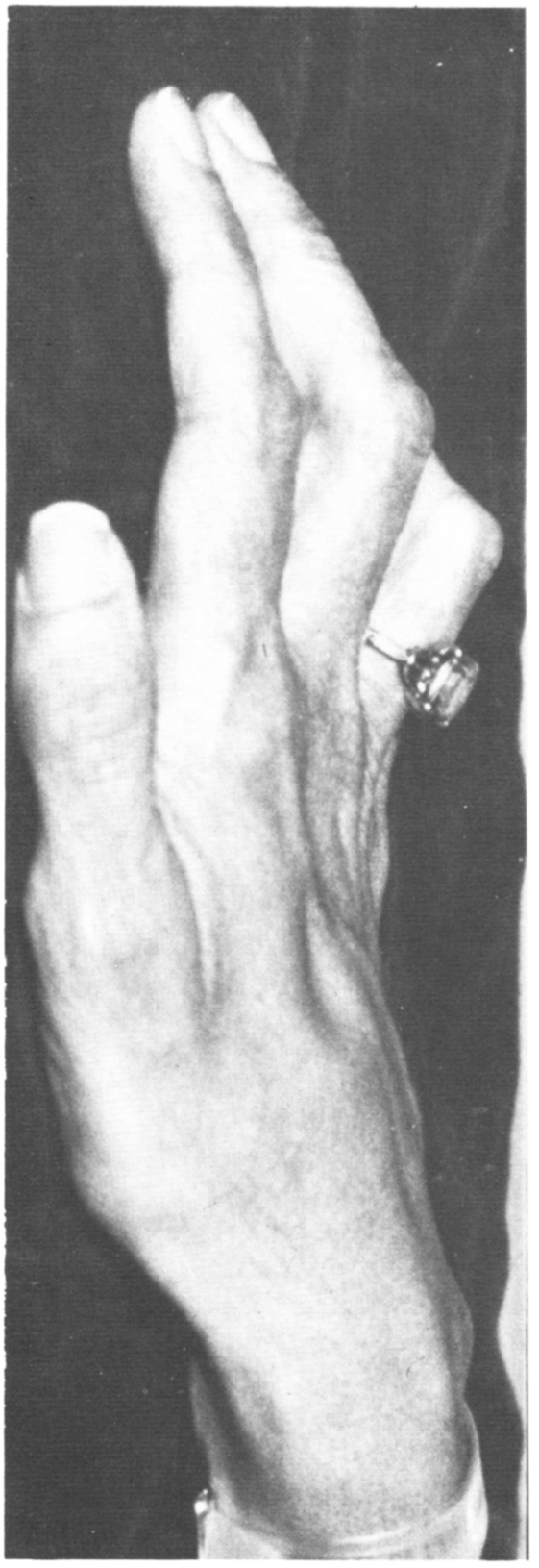

Figure 2-Clawhand is sometimes seen in this form of spastic ataxia and most of the patients exhibit some degree of intrinsic amyotrophy.
Involunatry dystonic or athetoid movements of the face and right shoulder were noted once among the hospitalized patients and this patient also had fasciculations in the lower limbs. In the field study, the presence of fine hand tremor, facial grimaces and jerky movements of the face and neck were noted in some patients. In others, dystonic postures were intermixed with choreic-like movements. Although definite on close examination by a trained observer, these movements, nevertheless, were not a major feature. There were no paresthesiae but 9/14 patients complained of painful cramps in various territories (neck, upper or lower limbs) and conditions (rest, sleep, exertion).

Skull and chest X-rays were all normal. Anterior-posterior (AP) view of the spine was obtained from fourteen erect patients and showed in five cases a non significant thoracic curve of less than $10^{\circ}$. True kyphoscoliosis was never seen. Two patients had air encephalograms, with tomography of the posterior fossa demonstrating severe cerebellar atrophy.

\section{D) Ocular Findings}

Ophthalmological examination, including color vision testing and photography of the fundi, was done on the 14 patients admitted. Six patients had electroretinographic and

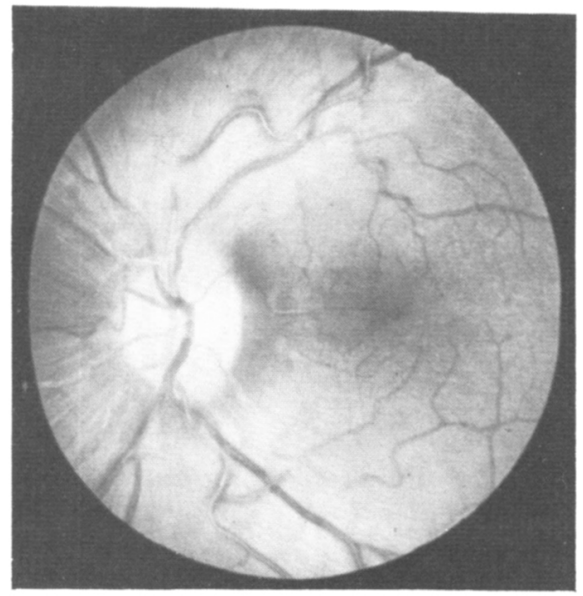

Figure 3-Increased visibility of the retinal nerve fibers, hiding parts of the vessels is seen in all cases of this study. electrooculographic studies (ERG EOG). Five patients had normal potentials. One had photopic and scotopic abnormalities but her vision was 20/20 in both eyes with normal color vision.

Visual acuity was normal in all cases, but one patient had an amblyopic eye $(20 / 70)$ explained by anisometropia. Refraction abnormalities (ametropia) were frequent. Six patients were myopic $(-1.00$ to -3.75) and four hyperopic ( $<+$ 2.50). One patient had a unilateral congenital blepharoptosis and another had antimongoloid palpebral fissures and hyperactive superior oblique muscles but no obvious strabismus. No paralytic strabismus was found, but two patients exhibited symptomatic weakness of convergence. Five patients had manifest strabismus, 3 with small angle exotropia and 2 with small angle intermittent esotropia. Ocular mobility defects have already been described.

Visual fields, color vision (Ishihara), slit lamp examination, search for cataracts, tonometry $(<20 \mathrm{~mm}$ $\mathrm{Hg}$ ), pupil size with intact light and near reflexes were all normal. Funduscopy showed normal optic discs in all patients, but striking and markedly increased visibility of the retinal nerve fibers, mainly in the papillomacular bundle area (Fig. 3). A somewhat similar increased thickness of these nerve fibers has been recently described in the early stage of Leber's hereditary optic atrophy. This disease is often found in conjunction with hereditary ataxia (Nikoskelainen et al., 1977). A number of papers have reported funduscopic abnormalities in hereditary ataxia, although seldom with failing visual acuity. Brégeat (1966) has studied the association of hereditary nervous system degenerative diseases and optic atrophy and concluded that it was different from Leber's atrophy, where vision is rapidly lost. Central retinal degeneration has been reported with spastic ataxia (Bergstedt et al., 1962).

\section{E) Psychometric Evaluation}

The Ottawa-Wechsler intelligence battery was administered to 
twenty-one patients, 13 females and 8 males, including the fourteen patients admitted to hospital. The mean $\mathrm{z}$-scores (mean equals 0 and standard deviation equals 1 for the entire population) of each scale adjusted for age is presented in table 3 . Our ataxic patients scored below normal in the non-verbal scales. For digit symbols, the low score may be partly related to the physical handicap, since the test requires speed and good motor control of fine movements. However, the physical handicap does not explain the low scores for the rest of the non-verbal scales. Some of our low score patients could draw an accurate spiral and quite a few patients with poor spiral drawing scored quite high. In addition, it was obvious during the tests that some patients had marked difficulties with picture or block arrangements that had little or nothing to do with motor control.

A t-test for paired data has been calculated between verbal I.Q. and non-verbal I.Q. (Table 4) and shows a significant difference $(\mathrm{p}<0.01)$. Familial spastic ataxia seems to be associated with a decrease in nonverbal mental abilities. There was no correlation with handedness and no significant difference between males and females, although female patients scored slightly lower (respectively 81 and 76). Verbal abilities were less influenced. With a mean of 92.67 for verbal I.Q., we concluded that our group of ataxia patients were within the limits of normal, similar to the typical Friedreich's ataxia patients studied by Geoffroy et al. (1.976).

We have also identified two nonverbal scales (object assembly and digit symbol) that are in negative correlation with age. This suggests that abilities decrease significantly as age increases, or as the disease progresses. These correlations are respectively: -41 and -31 for object assembly and digit symbol. This tends to suggest that correlations need to be looked for with all the sub-tests of the non-verbal as well as the verbal scale. This appears to be more important than the global I.Q. studies which are an average of many different mental abilities.

\section{F) Cardiovascular Evaluation}

The fourteen patients of this study underwent cardiovascular evaluation as well as chest X-rays, electrocargiograms, vectocardiograms and echocardiograms.

Clinical findings: Five patients had normal cardiovascular examinations. In one case, there was a grade I/VI ejection systolic murmur at the upper left sternal border which disappeared with the Valsalva maneuver. In six patients there was an early systolic click, best heard at the apex, and in two additional patients a similar click was followed by an early and mid-systolic murmur. This is usually considered clinical evidence for prolapse of the mitral value.

Chest X-rays: The heart size was normal (normal $\mathrm{C} / \mathrm{T}$ ratio) as well as the pulmonary vascularity in each case.

Electrocardiograms and vectocardiograms: The E.C.G. tracing was normal in thirteen patients. The other exhibited occasional premature ventricular contractions but the tracing was otherwise normal. The vectocardiogram was normal in all twelve patients in whom it was obtained.

Echocardiogram: Tracings were obtained in 12 of the 14 patients. The echocardiogram was entirely normal in two. In one case it showed slight dilatation of the left and of the right ventricle. One patient exhibited a very slight degree of septal hypertrophy, with the septal to posterior wall ratio of 1.37 at end-diastole. Eight tracings showed the echocardiographic features of prolapse of the mitral valve. In seven cases, the prolapse was of the early or pansystolic type, whereas in the last patient it was of the mid-systolic type. None of the fourteen patients exhibited the echocardiographic features of Friedreich's ataxia (Gattiker et al., 1976). Instead, a high incidence of mitral valve prolapse was found. Three patients had clinical, but no echocardiographic, evidence of prolapse. In three others there was echocardiographic prolapse without any physical signs. In five patients there was both clinical and echocardiographic evidence of the anomaly.

\section{G) Electrophysiological Study}

Nerve conduction studies and EMG's were carried out on the hospitalized patients. They revealed absent or markedly decreased sensory evoked potentials. However, in line with the increased CSF proteins and the peripheral muscle atrophy, motor conduction (Dyck et al., 1968, 1971; Peyronnard et al., 1976) was decreased in most patients in this group. Polyphasic motor units in many muscles confirmed neurogenic involvement. These studies are reported in detail in a later paper.

\section{H) Laboratory results}

Each of the fourteen patients was admitted to hospital for ten days. During the first three days they were placed on a diet balanced for proteins and sugars before the routine and special fasting blood tests were done. Determination of total serum bilirubin was done on three consecutive days. Cerebrospinal fluid was obtained by lumbar puncture for analysis of proteins by electrophoresis, and by chromatography for endogenous opiates and peptides.

Methods: Aldolase, serum glutamate oxalo-acetate transaminase (SGOT) and pyruvate transaminase (SGPT), creatinine phosphokinase (CPK) and triglycerides were estimated using Gemsaec at $30^{\circ} \mathrm{C}$. Serum lactate dehydrogenase was measured with the kit Statzyme LDH (L-P) 16 by ICN and total serum cholesterol with the kit of Beohringer-Mannheim. Lactic and pyruvic acid were estimated with the kit of Sigma Chemical Co. Conjugated and unconjugated bilirubin were estimated by the method of Malloy and Evelyn (1937). Serum and cerebrospinal fluid proteins were determined by the methods of Grunbaum (1963) and Kaplan and Savary (1965).

\section{RESULTS}

a) Distribution of $\mathrm{ABO} / \mathrm{Rh}$ blood types for this group of patients showed an increase in type $\mathrm{B}+$ (28.5\%), which is more than the normal population of Quebec (9\%) and the Friedreich's ataxia population (Butterworth et al., 1976). 
DISTRIBUTION OF TOTAL BILIRUBIN

TOTAL BILIRUBIN (MG 7)

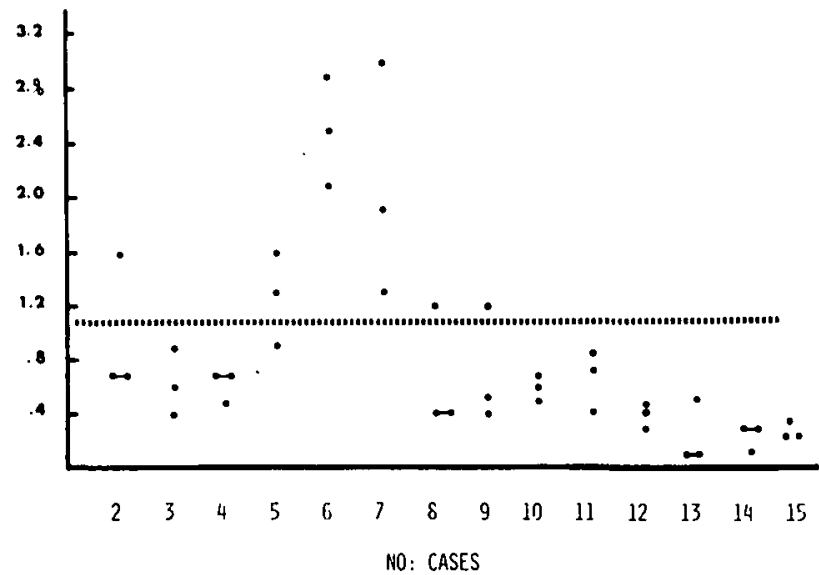

Figure 4-Distribution of total bilirubin results for each patient in the study.
PYRUVATE LEVELS DURING

GLUCOSE TOLERANCE TEST

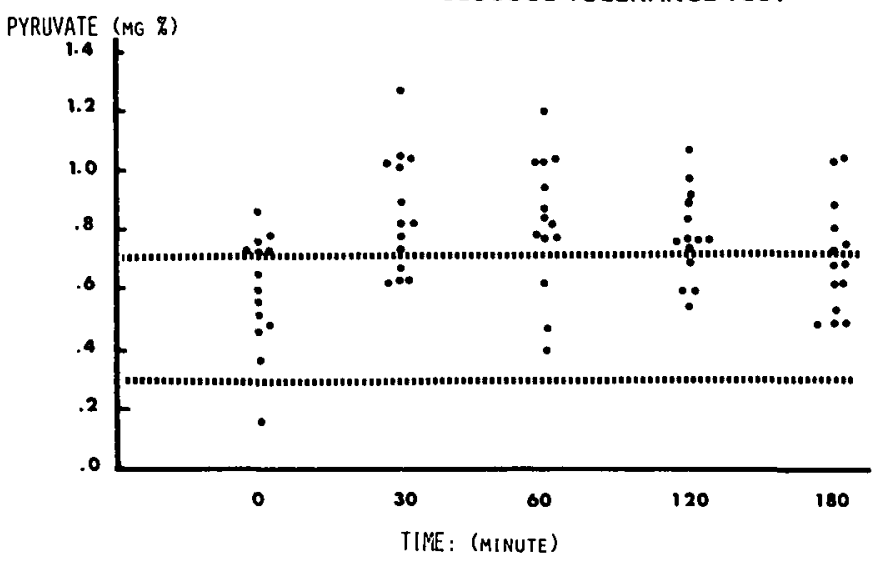

Figure 5-Pyruvate levels during glucose tolerance test for each patient. Mean value at start time is $0.59 \pm .172 \mathrm{mg} \%$ and peaks to $0.825 \pm .227 \mathrm{mg} \%$ at 60 minutes. After 180 minutes it is still elevated at $0.68 \pm .19 \mathrm{mg} \%$.
However, it should be remembered that they all originate from the same family group. Other hematologic data are normal, but we found a single patient with a spoliative anemia and another with discrete acanthocytosis.

b) Serum enzyme activities as well as the levels of cholesterol and triglycerides were normal in all patients by routine tests (see paper by Davignon et al., this issue). Serum protein electrophoresis did not show any quantitative or qualitative modification.

c) Total bilirubinemia was in-creased in six patients $(1.6,1.6,2.9$, $3.0,1.1,1.2 \mathrm{mg} \%$ ) at least once (Fig. 4). We did not find a familial distribution to this as described by Barbeau et al. (1976) in Friedreich's ataxia. Three determinations of bilirubin for each patient gave the following mean values: conjugated $0.104 \pm 0.108 \mathrm{mg} \%$, unconjugated $0.318 \pm 0.262 \mathrm{mg} \%$ and total bilirubin $0.536 \pm 0.55 \mathrm{mg} \%$.

d) Pyruvic and lactic acids were determined during a glucose tolerance test. As with Friedreich's ataxia, we found a delayed return to normal, indicating impaired pyruvate oxidation (Fig. 5). Six patients had a slightly elevated pyruvate level when fasting. One hour after the glucose load, eleven patients had an increased level and after three hours six were still elevated. However, the pyruvate oxidation defect appears to be of much less importance than in Friedreich's ataxia (Barbeau et al., 1976c).

e) The cerebrospinal fluid had normal cellular content in all cases. Total C.S.F. proteins were increased in 9 cases with a range of 18 to $87.5 \mathrm{mg} \%$. Contrary to the results of Badiu and Cherciulescu (1969) and in hereditary ataxia, C.S.F. albumins were increased in 7 cases and $\beta$-globulins decreased in 10 cases, although these values were not significant when compared to a group of 26 controls with neurological diseases other than brain hemorrhages or multiple sclerosis. A relative decrease in $\alpha_{2}$ and $\beta$-globulins in C.F.S. has been noted in atrophic degenerative processes (Kawi, 1973) and we also found $\alpha_{2}$ globulins decreased in 7 of our cases.

\section{DISCUSSION}

We have described a large group of patients from a genetic isolate, presenting a uniform clinical picture and best fitting the general description of familial spastic ataxia. The clinical features of these patients are more homogeneous than in the cases from around the world which were first called spastic ataxia by Bell and Carmichael almost forty years ago. No other published family or kindred presents the range of clinical, electrophysiological and biochemical manifestations encountered in the syndrome seen in the Charlevoix-Saguenay area.

The first distinctive feature is the genetic transmission. Contrary to the autosomal dominant form of hereditary spastic paraplegia (Landau and Gitt, 1951) which is the most common form of presentation, in our cases the transmission was autosomal recessive. Recessive spastic ataxia has been reported rarely. Hogan and Bauman (1977), in a thorough review of familial spastic ataxia, stated that the recessive form is more frequent in childhood, but further in their paper they analyze jointly the recessive and dominant cases reported in the literature, thus further contributing to the confusion. Cross and McKusik (1967a), while describing the Troyer Syndrome in the Old Order Amish of Holmes County, Ohio, reviewed the literature concerning recessive cases of spastic ataxia. The data is computed in Table 6, modified from their paper. It can be seen that a clinical tetrad of spasticity, dysarthria, distal muscle wasting and foot deformities is common to all previously reported cases of recessive (familial) spastic ataxia, and even to some cases inherited in an autosomal dominant fashion (Garland and Astley, 1950). 
TABLE 5

\begin{tabular}{|c|c|c|c|c|c|}
\hline \multirow[b]{3}{*}{ TOTAL PROTEIN } & \multirow[b]{2}{*}{ NORMALITY } & \multicolumn{2}{|c|}{$\begin{array}{l}\text { HEREDIIARY } \\
\text { SPASTIC ATAXIA } \\
(\mathrm{N}=14)\end{array}$} & \multicolumn{2}{|c|}{$\begin{array}{l}\text { NEUROLOGICAL } \\
\text { CONIROLS } \\
(\mathrm{N}=26)\end{array}$} \\
\hline & & MEANS & S.D. & MEANS & S.D. \\
\hline & $15-40 \mathrm{mg} 8$ & 53.35 & 24.66 & 34.23 & 23.6 \\
\hline PRE-ALBUMIN & $2-4.5 \mathrm{mg} q$ & 5.3 & 2.6 & 6.65 & 2.57 \\
\hline ALBUMMNN & $47-60 \mathrm{mg} 8$ & 59.47 & 5.31 & 56.16 & 4.74 \\
\hline$\alpha_{2}$ GLOBULIN & $6.5-10 \mathrm{mg} 8$ & 6.90 & 1.67 & 7.62 & 1.34 \\
\hline B GLOBULIN & $15.5-24 \mathrm{mg} 8$ & 14.34 & 2.35 & 15.08 & 2.8 \\
\hline
\end{tabular}

To this may be added onset before age two as reported by Seeligmuller (1876), Holmes (1905), in the Troyer Syndrome (Cross and McKusick, 1967a) and in the CharlevoixSaguenay syndrome. The disease in Quebec is progressive, even if relatively slow. This is also the case in the Troyer Syndrome. Nystagmus and abnormal pursuit movements were present in all our cases, but have not been noted in the Troyer Syndrome.

Although superficial sensory modalities were normal in all the reported cases and in our patients, we found vibration perception and

position sense in the legs was decreased. This was confirmed by the complete absence of sensory evoked potentials in the lower limbs in our patients. This distinctive feature has not previously been reported (although not usually tested for). Another distinctive feature found in all our cases was a retinal striation, which has recently been reported in early cases of Leber's optic atrophy (Nikoskelainen et al., 1977). Finally, in a significant proportion of cases there was mitral valve prolapse, a heretofore undescribed finding in ataxia.

The Charlevoix-Saguenay syn- $\underline{\text { TABLE } 6}$

RECESSIVE SPASTIC ATAXIA IN THE LITERATURE

$\frac{\text { SEELICMULLER }}{(1876)} \frac{\text { HODGE }}{(1897)} \frac{\text { MAAS }}{(1904)} \quad \frac{\text { ORMEROD }}{(1904)} \quad \frac{\text { HOLMES }}{(1905)} \frac{\frac{\text { TROYER }}{\text { SINDROME }}}{(1967)} \frac{\frac{\text { CHARLEVOIX }}{(1977)}}{\frac{\text { SAGJENAY }}{4}}$

$\begin{array}{lrrrrrrr}\text { Cases males } & 1 & 1 & 1 & 3 & 0 & 13 & 25 \\ \quad 3 & 2 & 1 & 0 & 2 & 7 & 17 \\ \text { Onset (yr) } & 3 & 10 & 12 & 3-6 & 1-2 & 1-2 & 1-2 \\ \text { Spasticity } & 1 & + & + & + & + & + & + \\ \text { Dysarthria } & + & + & + & 0 & + & + & + \\ \text { Distal wasting } & + & + & + & + & + & + & + \\ \text { Foot deformities } & + & + & + & ? & + & + & + \\ \text { Nystagmus } & ? & + & ? & + & + & 0 & + \\ \text { Sensory abnomalities } & 0 & 0 & 0 & 0 & 0 & 0 & + \\ \text { Mitral prolapse } & ? & ? & ? & ? & ? & ? & +\end{array}$

drome appears to be a distinct entity, or at least a more advanced form of previously described recessive spastic ataxias. However, on genetic, clinical and even biochemical grounds there is some evidence linking recessive spastic ataxia and Friedreich's ataxia. This possibility had been raised by Bell and Carmichael (1939) and has been mentioned by many authors. Both are rare recessive diseases. It is of interest that all the known kinships of the Charlevoix-Saguenay syndrome have among their ancestors one of the couples previously identified in many Friedreich's ataxia kinships: Robert Drouin and Marie Dubois (Barbeau et al., 1976a). However, direct links with the Friedreich's families have not been established. Clinically, it is important to note the involvement of the posterior columns in both diseases. Finally, there are a number of biochemical similarities. In both diseases there are groups of patients with slow pyruvate oxidation rates, with elevated indirectreacting bilirubin, with decreased $\beta$-lipoproteins in the serum (see paper by Wastiaux et al. in this issue) or with low HDL apoproteins (see paper by Davignon et al. in this issue). Such similarities pose a number of nosologic problems which will have to be solved by future studies. However, major differences such as the mitral prolapse rather than cardiomyopathy and the increased tendon reflexes exist between the two diseases.

\section{ACKNOWLEDGMENTS}

These studies were supported by grants from l'Association Canadienne de l'Ataxie de Friedreich.

\section{REFERENCES}

ANDERMANN, E., ANDERMANN, F., CARPENTER, S., KARPATI, G., EISEN, A., MELANCON, D. and BERGERON, J. (1976). Familial agenesis of the corpus callosum with sensorimotor neuropathy: a new autosomal recessive syndrome originating in Charlevoix county (abstract). Can. J. Neurol. Sci., 3, 155.

BADIU, G, and CHERCIULESCU, F. (1969). A biochemical test for differential diagnosis between acanthocytosis and 
spino-cerebellar degenerations. Europ. Neurol., 2, 315-317.

BARBEAU, A., LESIEGE, M., BRETON, G., COALLIER, R. and BOUCHARD, J. P. (1976a). Friedreich's ataxia: Preliminary results of some genealogical research. Can. J. Neurol. Sci., 3, 303-306.

BARBEAU, A., BRETON, G., LEMIEUX, B. and BUTTERWORTH, R. F. (1976b). Bilirubin metabolism in Friedreich's ataxia - Preliminary investigation. Can. J. Neurol. Sci., 3, 365-372.

BARBEAU, A., BUTTERWORTH, R. F., NGO, T., BRETON, G., MELANCON, S., SHAPCOTT, D., GEOFFROY, G. and LEMIEUX B. (1976c). Pyruvate metabolism in Friedreich's ataxia. Can. J. Neurol. Sci.. 3, 379-388.

BELL, J. $M$. and CARMICHAEL, E. A. (1939). On hereditary ataxia and spastic paraplegia. In: Treasury of Human Inheritance, Vol. 4, Cambridge Press, London, pp. 141-284.

BERGSTEDT, M., JOHANSSON, S. and MULLER, R. (1962). Hereditary spastic ataxia with central retinal degeneration and vestibular impairment. Neurol., 12, 124-132.

BREGEAT, P. (1966). L'atrophie optique dans les hérédo-dégénérescences nerveuses systématisées. J. Gent. Hum., 15, 263-283

BUTTERWORTH, R. F., SHAPCOTT, D., MELANCON, S., BRETON, G., GEOFFROY, G., LEMEIUX, B. and BARBEAU, A. (1976). Clinical laboratory findings in Friedreich's ataxia. Can. J. Neurol. Sci., 3, 355-359.

CROSS, H. E. and McKUSICK, V. A. (1967a). The Troyer syndrome - a recessive form of spastic paraplegia with distal muscle wasting. Arch. Neurol., 16, 473-485.

CROSS, H. E. and McKUSICK, V. A. (1967b). A survey of neurological disorders in a genetic isolate. Neurol., 17, 743-751.

DYCK, P. J. and LAMBERT, E. H. (1968). Lower motor and primary sensory neuron diseases with peroneal muscular atrophy (II). Arch. Neurol., 18, 619-625.

DYCK, P. J., LAMBERT, E. H. and NICHOLS, P. C. (1971). Quantitative measurement of sensation related to com- pound action potential and number and sizes of myelinated and uninyelinated fibers of sural nerve in health, Friedreich's ataxia, hereditary sensory neuropathy, and tabes dorsalis. In: Handbonk of Electroencephalogr. Clin. Neurophysiol. Vol. 9, Elsevier, Amsterdam. pp. 83-118.

FERGUSON, F. R. and CRITCHLEY, $M$. (1929), A clinical study of an heredofamilial disease resembling disseminated sclerosis. Brain, 52, 203-225.

GARLAND, H. G.and ASTLEY, C. E. (1950). Hereditary spastic paraplegia with amyotrophy and pes cavus. J. Neurol. Neurosurg. Psychiat., 13, 130-133.

GATTIKER, H. F., DAVIGNON, A. BOZIO. A.. BATTLE-DIAZ, J., GEOFFROY, G., LEMIEUX, B. and BARBEAU, A. (1976). Echocardiographic findings in Friedreich's ataxia. Can. J . Neurol. Sci., 3, 329-332.

GEOFFROY, G., BARBEAU, A., BRETON, G., LEMIEUX, B., AUBE, M. LEGER, C and BOUCHARD, J. P. (1976) Clinical description and roentgenologic evaluation of patients with Friedreich's ataxia. Can. J. Neurol. Sci. 3, 279-286.

GRUNBAUM, B. W. (1963). Evaluation of a cellulose-acetate electrophoresis system for serum protein fractionation. Microch. Journ., 7, 41-53.

HODGE, G. (1897). Three cases of Friedreich's Disease all presenting marked increase of the knee jerk. Brit. Med. J., 1, 1405-1406.

HOGAN, G. R. and BAUMAN, M. L. (1977). Familial spastic ataxia: Occurrence in childhood. Neurol., 27, 520-526.

HOLMES, G. (1905). Family spastic paralysis associated with amyotrophy. Rev. Neurol. Psychiat., 3, 257-263.

JOHNSTON, A. W. and McKUSICK, V. (1962). A sex-linked recessive form of spastic paraplegia. Amer. J. Hum. Genet., 14, 83-94.

KAPLAN, A. and SAVARY, H. (1965). Application of an improved microelectrophoresis technique and Immunoelectrophoresis of the serum proteins on cellulose acetate. Clin. Chem., 11, 937-942.

KAWAI, T. (1973). Clinical aspects of the plasma proteins. J. B. Lippincott Company, Philadelphia, pp. 125-130.

LABERGE, C. (1969). Hereditary tyro- sinemia in a French Canadian isolate. Amer. J. Hum. Genet., 21, 36-45.

LANDAU, W, M. and GITT. J. J. (1951). Hereditary spastic paraplegia and hereditary ataxia. Arch. Neurol. Psychiat.. 66. 346-354.

MAAS, O. (1904). Lieber ein selten beschriebenes familiäres Nervenleiden. Berlin Klin. Wschr., 41, 832-833.

MALLOY, H. and EVELYN. K. (1937). Determination of bilirubin with the photoelectric colorimeter. J. Biol. Chem.. 119, 481.

NETSKY, M. G. (1968). Degeneration of the cerebellum and its pathways. In: Pathology of the nervous system. Minckler, Editor. McGraw-Hill. New York, pp. 1163-1185.

NIKOSKELAINEN, E., SOGG, R. L... ROSENTHAL. A. R.. FRIBERG, T. R. and DORFMAN. L. J. (1977). The early phase in Leber hereditary optic atrophy. Arch. Ophtalmol. 95. 969-978.

ORMEROD, J. A. (1904). An unusual form of family paralysis. Lancet. I 17-18.

PEYRONNARD, J. M., BOUCHARD. J. P., LAPOINTE. L.. LAMONTAGNE. A.. LEMIEUX, B. and BARBEAU, A. (1976). Nerve conduction studies and electromyography in Friedreich's ataxia. Can. J. Neurol. Sci., 3. 313-317.

SCHUT. J. (1950). Hereditary ataxia : clinical study through six generations. Arch. Neurol. Psychiat., 63, 535-568.

SEELIGMÜLLER, A. (1876). Einige seltenere formen von affectomen des Rückenmarks: 1. Sklerose der Seintenstränge des Rückenmarks bei vier Kindern derselben Familie. Deutsch Med. Wschr.. 2. 185-186.

SILVER, J. R. (1966). Familial spastic paraplegia with amyotrophy of the hands. J. Neurol. Neurosurg. Psychiat., 29. 135-144.

TYRER, J. H. and SUTHERLAND, J. M. (1961). The primary spino-cerebellar atrophies and their associated defects. with a study of the foot deformity. Brain, 84, 289-300.

WADIA, H. and SWAMI, R. K. (1971), A new form of heredo-familial spinocerebellar degeneration with slow eye movements. Brain, 94, 359-374.

ZEE, D. S., YEE, R. D., COGAN, D. G., ROBINSON, D. A. and ENGEL, W. K. (1976). Ocular motor abnormalities in hereditary cerebellar ataxia. Brain, 99. 207-234. 